\title{
The role of effectors in nonhost resistance to filamentous plant pathogens
}

\author{
Remco Stam ${ }^{1}$, Sophie Mantelin ${ }^{2}$, Hazel McLellan ${ }^{1}$ and Gaëtan Thilliez ${ }^{1,2}$ \\ ' Division of Plant Sciences, University of Dundee - The James Hutton Institute, Dundee, UK \\ ${ }^{2}$ Cell and Molecular Sciences, The James Hutton Institute, Dundee, UK
}

\section{Edited by:}

Benjamin Schwessinger, University of California, Davis, USA

\section{Reviewed by:}

Ralph Panstruga, RheinischWestfälische Technische Hochschule Aachen University, Germany Roger Wise, United States Department of Agriculture-Agricultural Research Service and lowa State University, USA

\section{*Correspondence:}

Remco Stam, Division of Plant Sciences, University of Dundee - The James Hutton Institute, Invergowrie, Dundee DD2 5DA, Scotland, UK e-mail:r.stam@dundee.ac.uk
In nature, most plants are resistant to a wide range of phytopathogens. However, mechanisms contributing to this so-called nonhost resistance (NHR) are poorly understood. Besides constitutive defenses, plants have developed two layers of inducible defense systems. Plant innate immunity relies on recognition of conserved pathogen-associated molecular patterns (PAMPs). In compatible interactions, pathogenicity effector molecules secreted by the invader can suppress host defense responses and facilitate the infection process. Additionally, plants have evolved pathogen-specific resistance mechanisms based on recognition of these effectors, which causes secondary defense responses. The current effector-driven hypothesis is that NHR in plants that are distantly related to the host plant is triggered by PAMP recognition that cannot be efficiently suppressed by the pathogen, whereas in more closely related species, nonhost recognition of effectors would play a crucial role. In this review we give an overview of current knowledge of the role of effector molecules in host and NHR and place these findings in the context of the model. We focus on examples from filamentous pathogens (fungi and oomycetes), discuss their implications for the field of plant-pathogen interactions and relevance in plant breeding strategies for development of durable resistance in crops.

Keywords: effectors, nonhost resistance, filamentous plant pathogens, oomycetes, fungi

\section{INTRODUCTION}

In nature, successful pathogens are the exception, as the majority of plants are resistant to most pests and pathogen species. This form of disease resistance is known as nonhost resistance (NHR) and can be defined as resistance exhibited by an entire plant species to all genetic variants of a non-adapted pathogen species or forma specialis (f. sp.). Multiple factors contribute to NHR to unadapted pathogens, including constitutive defenses and induced defense mechanisms that result in plant immunity (Uma et al., 2011; Fan and Doerner, 2012).

Plant structure and chemistry form the first barriers encountered by any filamentous plant pathogen. The pathogen must locate a potential host. Variation in chemical compounds released by the plants can affect the attraction process (Morris and Ward, 1992). Once in contact, spores must germinate and form appressoria in order to penetrate the tissues. Both these processes are partly mediated by plant chemical components in compatible interactions (Ruan et al., 1995). Finally, the pathogen needs to find an appropriate source of nutrients in its host and thus the metabolic status of the plant can selectively determine its host/nonhost status (Stuttmann et al., 2011).

If the pathogen is able to overcome these barriers, it will face induced plant defenses. Most pathogens are defeated following detection of conserved pathogen molecules (Pathogen-Associated Molecular Patterns, PAMPs) by host cell surface pattern recognition receptors (PRRs) which activate pattern-triggered immunity (PTI; Zipfel, 2009). PAMPs are frequently parts of structural molecules that are essential for the pathogens and that cannot be readily changed to avoid their detection. However, adapted pathogens either evade recognition or suppress triggered plant defenses as summarized by the so-called Zigzag model (Jones and Dangl, 2006): PTI renders plants resistant, but pathogens deliver effector molecules thought to act in the apoplast or inside the plant cell, suppressing PTI (e.g., de Jonge et al., 2011; Wawra et al., 2012). In order to counter this, plants have a second layer of immune receptors encoded by resistance $(R)$ genes, mainly nucleotidebinding - leucine-rich repeat (NB-LRR) proteins which upon activation, lead to effector-triggered immunity (ETI; Elmore et al., 2011). The ETI response is accompanied in most cases by a hypersensitive reaction (HR) - a localized programmed cell death which is believed to prevent the spread of biotrophic pathogens from the infection site.

The role of plant receptors involved in both PTI and ETI as well as the pathogen effector arsenal are generally considered as the core components of the battleground in plant-pathogen interactions and NHR has been proposed to be largely based either on PTI in the absence of defense suppression, or on ETI from stacks of $R$ genes (Schweizer, 2007; Niks and Marcel, 2009). Following this, a model of NHR was proposed by Schulze-Lefert and Panstruga (2011) that focused on inducible plant defenses and disregarded preformed defenses and physical cues. With respect to this condition, the model suggests that NHR in plants that are evolutionary distantly related to the natural host is predominantly triggered by PRR-mediated recognition, as PTI cannot be suppressed by the pathogen. By contrast, in more closely related species nonhost recognition of effectors and ETI are proposed 
to play a predominant role. In this review, we not only give an overview of current knowledge of the central role played by pathogen recognition systems and effectors in host and NHR but we also place these findings in the context of the NHR model. We focus on plant interaction with filamentous pathogens, and the relevance of NHR in plant breeding strategies for development of sustainable broad-spectrum resistance in crops.

\section{GENOMICS ADVANCES REVEAL EFFECTOR AND $\boldsymbol{R}$-GENE DIVERSITY}

Many genomes from filamentous phytopathogens have been sequenced, including both biotrophic and necrotrophic oomycetes (Haas etal., 2009; Baxter et al., 2010; Levesque et al., 2010) and numerous fungi with different lifestyles (Dean et al., 2005; Ma etal., 2010; Spanu etal., 2010; de Wit etal., 2012). Genomescale analysis reveals that large numbers of putative effector genes are present in these phytopathogens. Some effectors occur in large families and the best-characterized examples are the RXLR and crinkling and necrosis (CRN) effectors in the oomycete genus Phytophthora. These families comprise 100s of genes (Haas et al., 2009; Shen etal., 2013; Stam et al., 2013). In fungi such large effector families with a common, defining, sequence motif appear to be absent. Nonetheless 100s of individual effectors and smaller effector families have been identified, including the conserved LysM effectors that protect Cladosporium spp. against chitin-associated defense responses (Bolton et al., 2008; Kombrink and Thomma, 2013), divergent families of cell wall degrading enzymes (CWDE; Ma et al., 2010; Spanu et al., 2010), clusters of putative cytoplasmic effectors (Saunders et al., 2012) and diverse families of Candidates for Secreted Effector Proteins (CSEPs) in the barley powdery mildew fungus (Pedersen et al., 2012).

The different mechanisms through which genomic and effector diversity within and between species can occur have recently been reviewed (e.g., Gladieux et al., 2014; Stukenbrock and Croll, 2014). Genome analyses show that many phytopathogens have a distinct genomic make-up. Nearly all show specific clustering patterns of genes. Isochore-like regions, which are CG-rich and non-coding, have been identified in the Ascomycota fungus Leptosphaeria maculans (Rouxel et al., 2011). The few genes present in these regions show important variation between populations. Verticillium dahliae genomes show characteristics of chromosomal reshuffling and harbor lineage-specific regions (LS) flanking chromosomal breakpoints. These LS are enriched for retrotransposons and other repetitive sequence elements (de Jonge et al., 2013). In the oomycete $P$. infestans a similar phenomenon has been described, where gene-dense regions are interspersed with gene-poor regions (Raffaele et al., 2010b). Effectors are frequently located in these "plastic" genomic regions. This observation prompted the hypothesis that this configuration allows for rapid effector diversification, thus allowing the pathogen to adapt to rapidly changing environments and to overcome resistance, a process also referred to as the two-speed-genome (Haas et al., 2009; Raffaele et al., 2010a; Raffaele and Kamoun, 2012; Karasov et al., 2014).

Similarly, as more plant genomes are sequenced, it is possible to compare their $R$-gene composition. These analyses show that the number of predicted $R$ genes varies considerably from one species to another, even taking relative genome size into account: e.g., 54 in papaya ( 370 MB; Porter et al., 2009); 149 in Arabidopsis ( $125 \mathrm{MB}$; Arabidopsis Genome Initiative, 2000; Meyers, 2003); ca. 500 in rice ( 400 MB; Monosi et al., 2004; Rice Genome Project, 2005). Reported numbers are likely to be an under-estimate of the $R$ genes present in each genome; the use of an enrichment technology (RenSeq) allows targeted sequencing, focusing on the NB-LRR composition. Using RenSeq, the number of predicted $R$ genes present in the potato genome increased from 438 predicted in the original genome sequence, to 755 after enrichment (Jupe et al., 2012, 2013).

These genome studies suggest that effectors and $R$ genes are under evolutionary pressure. Indeed, signatures of positive selection have been shown for effectors (Win et al., 2007), their targets (Kaschani et al., 2010), and $R$ genes in Arabidopsis spp. (Mondragon-Palomino et al., 2002; Chen et al., 2010). However, comparative genomic studies as described above do not directly prove that effectors and $R$ genes play roles in pathogen host range or nonhost recognition.

\section{EFFECTOR RECOGNITION IN HOST AND NONHOST PLANTS}

The oomycete Phytophthora infestans causes disease in potato and tomato but it is unable to colonize the related solanaceous crop plant pepper (Capsicum annum). A screen of 54 P. infestans RXLR proteins in pepper revealed that many effectors are recognized in various pepper lines leading to a $\mathrm{HR}$ ( 7 on average and up to 36 in some accessions; Lee et al., 2014). Given that $P$. infestans has a predicted RXLR effector complement of $>500$ sequences and that $65 \%$ of the effectors tested in this study are detected and trigger a HR, this strongly suggests that NHR to P. infestans may be determined by recognition of multiple effector proteins. Similarly, a screen of 34 RXLR proteins from Bremia lactucae in 152 breeding lines of lettuce (Lactuca sativa) showed recognition of multiple effectors (Stassen et al., 2013). Two of these, BLG01 and BLG003, were recognized in 52 and two lines respectively. In addition, recent work on $P$. capsici has correlated NHR in a range of Nicotiana species with HR elicited by a single effector, PcAvr3alike (Vega-Arreguín et al., 2014). Moreover, Magnaporthe oryzae formae speciales are only pathogenic on their original host species and as such are reproductively isolated. Thus, artificial crosses between these pathogens allow the analysis of the hybrid progeny to identify genes restricting host range. Among these genes, some were identified that encode secreted effector proteins belonging to the PWL family, variants of which are expected to be recognized in nonhost plants (Kang et al., 1995; Sweigard et al., 1995; Tosa et al., 2006).

Besides the direct evidence that multiple effectors can be recognized in nonhost plants, genetic studies of resistance in cereals and lettuce to different filamentous pathogens highlighted that NHR is based on multiple quantitative trait loci (QTLs; Jafary et al., 2008; Jeuken et al., 2008; Zhang et al., 2009; Aghnoum and Niks, 2010). In barley, QTLs associated with NHR showed similarity in location with QTLs for basal resistance to Puccinia hordei (Jafary et al., 2008). Interestingly, these QTLs show different and overlapping specificities and contain several putative $R$ genes, suggesting that effector recognition might still play a role in this 
resistance. Besides, Zellerhoff et al. (2010) found that the differentially expressed genes in barley in response to closely related pathogens do not hugely differ between host and nonhost interactions but show distinct responses between the various pathogens. Interestingly, they also found a small cluster of genes overlapping between species, with similar functional annotations as those responsive to basal resistance. Unfortunately, the limited number of genes studied and the absence of pathogen data in this study, make it impossible to draw firm conclusions about the role of effector recognition in these interactions.

One way for a pathogen to avoid ETI is to lose recognized effectors. Whereas most effectors are thought to serve important functions during infection and seem to be indispensable, loss of effectors does not always lead to reduced fitness, most likely due to functional redundancy. For example, $P$. striiformis lacking effectors recognized by the wheat resistance protein Yr2 perform equally well on susceptible and Yr2 plants (Sørensen et al., 2013). Presence/absence polymorphisms are also common in Phytophthora RXLR and CRN effectors and in some cases, effector loss does not obviously affect fitness (Shan et al., 2004). A precursor to complete loss of effectors might be transgenerational gene silencing of effectors, as observed in P. sojae (Qutob et al., 2013). Thus, loss of recognized effectors in pathogen populations that are exposed to plants with cognate $R$ genes shows that effector recognition plays a crucial role in avoiding resistance.

\section{HOST SPECIFIC EFFECTOR FUNCTION}

In order for an effector to achieve its function and promote virulence, it is expected to manipulate one or more host target proteins or processes. One of the main ways effectors are thought to act is by suppressing defense responses activated during PTI. While there is a lot of evidence in the literature for effectors of filamentous pathogens suppressing immunity in host plants (de Jonge etal., 2011; Stassen and Van den Ackerveken, 2011) very little is known about effector function in distantly related nonhost plants, although CWDE from different phytopathogenic fungi show strongest enzymatic activity on their respective hosts (King et al., 2011). Recently, a protoplast expression system was used to identify RXLR effectors from $P$. infestans that were able to suppress PTI responses in a host (tomato) and in distantly related nonhost plant (Arabidopsis; Zheng et al., 2014). Of the 33 RXLR effectors screened, eight are able to suppress FRK1 (FLAG22-INDUCED RECEPTOR-LIKE KINASE 1) induction triggered by the PAMP flg22 in tomato. Interestingly, only three of the eight maintained this activity in Arabidopsis, suggesting the failure of the remaining five effectors to successfully manipulate their targets in the nonhost plant. Unfortunately, the effector targets in this case are yet not known.

Antonovics etal. (2013) described how failure of infection of a nonhost plant by pathogens could be an incidental byproduct of ongoing antagonistic evolution between adapted host and pathogens, a process they call non-evolved resistance. In agreement with this theory, recent work by Dong et al. (2014) demonstrated how effectors from two phylogenetically closely related oomycetes, $P$. infestans and $P$. mirabilis, evolved to specifically inhibit proteases from the distantly related plants tomato and four o'clock flower (Mirabilis jalapa) respectively. Cysteine proteases are involved in immunity and cell death signaling in plants (Gilroy et al., 2007; Shindo and van der Hoorn, 2007) and are known targets of effectors from fungi (Shabab et al., 2008; Mueller etal., 2013), oomycetes (Tian etal., 2006) and nematodes (Lozano-Torres et al., 2012). The effector PiEPIC1 from $P$. infestans is a cysteine protease inhibitor, which interacts with the proteases PIP1 and RCR3 in tomato. The homologue in P. mirabilis (PmEPIC1) is under diversifying selection compared to PiEPIC1. The genes corresponding to the equivalent proteases of tomato RCR3 were cloned from potato and four o'clock flower (Mirabilis RCR3-like protease 2, MRP2) and the inhibitory activity of each effector was analyzed. PiEPIC1 was able to efficiently suppress potato and tomato RCR3 activity but not MRP2 and the opposite was observed for PmEPIC1 (Dong et al., 2014). This supports the hypothesis that pathogens may be unable to suppress immunity in distantly related nonhost plants through failure of effectors to correctly manipulate their plant targets.

\section{UNDERSTANDING EFFECTOR ACTIVITY FOR NONHOST RESISTANCE BREEDING IN CROPS}

Studies presented in this review support the fact that effector recognition plays an important role in resistance or in susceptibility between closely related plant species. In this light, $R$ genes from related resistant crop species have been used for many years in breeding programs to provide resistance to specific isolates of a given pathogen species. Resistance genes from distantly related species have also been successfully introduced. For example, the introduction of the barley $R$ gene MLA1 in immunocompromised Arabidopsis mutants provided resistance to Blumeria graminis f. sp. hordei (Maekawa et al., 2012). Similarly, introduction of the tomato Ve1 gene in Arabidopsis conferred resistance to Verticillium spp. (Fradin et al., 2011). This shows that the mechanism involved downstream of the recognition event can be conserved between plant species, and even between monocotyledonous and dicotyledonous plants. Consequently the transfer of $R$ genes from a distantly related nonhost into a host plant could be used as a new source of resistance (Wulff et al., 2011). However, deployment of a single $R$ gene in a variety usually leads to resistance breakdown in the field within a couple of years and merely serves as an example of rapid adaptations that phytopathogens are capable of in natural and agricultural systems (Fry, 2008; Palloix et al., 2009; Stukenbrock and McDonald, 2009).

Transcriptomics studies of barley powdery mildew on immunocompromised Arabidopsis mutants revealed large effector sets that were similarly expressed early during compatible and incompatible interactions, but a reduction of effector expression in the presence of an active MLA1 R gene was observed (Hacquard et al., 2013). This suggests that a large number of effectors might be essential during infection and a subset of them may be recognized in nonhost interactions. The identification of indispensable effectors and their cognate $R$ genes could be a straightforward step toward resistance breeding in crops. However, recent studies show that a single point mutation in either NB-LRR or effector genes can alter the $R$-gene specificity or the effector function (Brunner et al., 2010; Segretin et al., 2014; Stirnweis et al., 2014). 
Alternative breeding strategies include modification of host genes targeted by effectors that are essential for the pathogen to establish itself, in order to artificially create the incompatibility observed in divergent host species. These genes are sometimes referred to as susceptibility $(S)$ genes (Vogel et al., 2002; Pavan et al., 2010; Lapin and Van den Ackerveken, 2013). Modification of $S$ genes is thought to be more durable; however, changing host proteins to avoid effector binding but retain normal functionality might prove to be very difficult (van Schie and Takken, 2014).

\section{CONCLUSION}

NHR is by definition more durable than host resistance; we have summarized here the recent findings supporting the idea that NHR is likely to be governed by multiple recognition events. However, effector recognition in distantly related nonhost plants has not frequently been observed. Taken together, the recent studies presented here rather support the original model of NHR proposed by Schulze-Lefert and Panstruga (2011). To determine involvement of effectors in NHR in distantly related crops, more comprehensive population genomics and transcriptomics studies will be required to advance our understanding of effector occurrence and expression within and between hosts and nonhosts as well as in pathogen populations. More studies are also required to examine effector function and recognition in both closely and distantly related nonhost plants. This work might help answer whether PTI does indeed play a greater role in NHR in more distal plant species. Alternatively it may find that the inability of the pathogen to modify crucial host processes due to lack of coevolution, in other words, the non-evolved resistance might already happen in closely related hosts. Additionally, we have highlighted two approaches that can be used to breed resistant plants. Whereas both approaches are very different, in both cases the study of effector proteins will be instrumental toward understanding the infection process and selecting appropriate target genes.

\section{ACKNOWLEDGMENTS}

We would like to thank Paul Birch, Ingo Hein, Edgar Huitema, John Jones, Jasmine Pham, Andrew Howden and other members of the Dundee Effector Consortium for useful discussions. This work was partly funded by the European Research Council (Grant nr 310901) and the BBSRC (grants BB/G015244/1, BB/K018183/1 and BB/K018299/1). The James Hutton Institute receives funding from the Rural and Environment Science and Analytical Services Division (RESAS) of the Scottish Government.

\section{REFERENCES}

Aghnoum, R., and Niks, R. E. (2010). Specificity and levels of nonhost resistance to nonadapted Blumeria graminis forms in barley. New Phytol. 185, 275-284. doi: 10.1111/j.1469-8137.2009.03039.x

Antonovics, J., Boots, M., Ebert, D., Koskella, B., Poss, M., and Sadd, B. M. (2013). The origin of specificity by means of natural selection: evolved and nonhost resistance in host-pathogen interactions. Evolution 67, 1-9. doi: 10.1111/j.15585646.2012.01793.x

Arabidopsis Genome Initiative. (2000). Analysis of the genome sequence of the flowering plant Arabidopsis thaliana. Nature 408, 796-815. doi: 10.1038/35048692

Baxter, L., Tripathy, S., Ishaque, N., Boot, N., Cabral, A., Kemen, E., et al. (2010). Signatures of adaptation to obligate biotrophy in the Hyaloperonospora arabidopsidis genome. Science 330, 1549-1551. doi: 10.1126/science.1195203

Bolton, M. D., van Esse, H. P., Vossen, J. H., de Jonge, R., Stergiopoulos, I., Stulemeijer, I. J. E., et al. (2008). The novel Cladosporium fulvum lysin motif effector Ecp6 is a virulence factor with orthologues in other fungal species. Mol. Microbiol. 69, 119-136. doi: 10.1111/j.1365-2958.2008.06270.x

Brunner, S., Hurni, S., Streckeisen, P., Mayr, G., Albrecht, M., Yahiaoui, N., et al. (2010). Intragenic allele pyramiding combines different specificities of wheat Pm3 resistance alleles. Plant J. 64, 433-445. doi: 10.1111/j.1365-313X.2010. 04342.x

Chen, Q., Han, Z., Jiang, H., Tian, D., and Yang, S. (2010). Strong positive selection drives rapid diversification of R-genes in Arabidopsis relatives. J. Mol. Evol. 70, 137-148. doi: 10.1007/s00239-009-9316-4

Dean, R. A., Talbot, N. J., Ebbole, D. J., Farman, M. L., Mitchell, T. K., Orbach, M. J., et al. (2005). The genome sequence of the rice blast fungus Magnaporthe grisea. Nature 434, 980-986. doi: 10.1038/nature03449

de Jonge, R., Bolton, M. D., Kombrink, A., van den Berg, G. C. M., Yadeta, K. A., and Thomma, B. P. H. J. (2013). Extensive chromosomal reshuffling drives evolution of virulence in an asexual pathogen. Genome Res. 23, 1271-1282. doi: $10.1101 /$ gr. 152660.112

de Jonge, R., Bolton, M. D., and Thomma, B. P. (2011). How filamentous pathogens co-opt plants: the ins and outs of fungal effectors. Curr. Opin. Plant Biol. 14, 400-406. doi: 10.1016/j.pbi.2011.03.005

de Wit, P. J. G. M., van der Burgt, A., Ökmen, B., Stergiopoulos, I., Abd-Elsalam, K. A., Aerts, A. L., et al. (2012). The genomes of the fungal plant pathogens Cladosporium fulvum and Dothistroma septosporum reveal adaptation to different hosts and lifestyles but also signatures of common ancestry. PLoS Genet. 8:e1003088. doi: 10.1371/journal.pgen.1003088

Dong, S., Stam, R., Cano, L. M., Song, J., Sklenar, J., Yoshida, K., et al. (2014). Effector specialization in a lineage of the Irish potato famine pathogen. Science 343, 552-555. doi: 10.1126/science. 1246300

Elmore, J. M., Lin, Z.-J. D., and Coaker, G. (2011). Plant NB-LRR signaling: upstreams and downstreams. Curr. Opin. Plant Biol. 14, 365-371. doi: 10.1016/j.pbi.2011.03.011

Fan, J., and Doerner, P. (2012). Genetic and molecular basis of nonhost disease resistance: complex, yes; silver bullet, no. Curr. Opin. Plant Biol. 15, 400-406. doi: 10.1016/j.pbi.2012.03.001

Fradin, E. F., Abd-El-Haliem, A., Masini, L., van den Berg, G. C. M., Joosten, M. H. A. J., and Thomma, B. P. H. J. (2011). Interfamily transfer of tomato Vel mediates Verticillium resistance in Arabidopsis. Plant Physiol. 156, 2255-2265. doi: $10.1104 /$ pp.111.180067

Fry, W. E. (2008). Phytophthora infestans: the plant (and R gene) destroyer. Mol. Plant Pathol. 9, 385-402. doi: 10.1111/j.1364-3703.2007.00465.x

Gilroy, E. M., Hein, I., van der Hoorn, R., Boevink, P. C., Venter, E., McLellan, H., et al. (2007). Involvement of cathepsin B in the plant disease resistance hypersensitive response. Plant J. 52, 1-13. doi: 10.1111/j.1365-313X.2007. 03226.x

Gladieux, P., Ropars, J., Badouin, H., Branca, A., Aguileta, G., de Vienne, D. M., et al. (2014). Fungal evolutionary genomics provides insight into the mechanisms of adaptive divergence in eukaryotes. Mol. Ecol. 23, 753-773. doi: $10.1111 / \mathrm{mec} .12631$

Haas, B. J., Kamoun, S., Zody, M. C., Jiang, R. H. Y., Handsaker, R. E., Cano, L. M., et al. (2009). Genome sequence and analysis of the Irish potato famine pathogen Phytophthora infestans. Nature 461, 393-398. doi: 10.1038/nature08358

Hacquard, S., Kracher, B., Maekawa, T., Vernaldi, S., Schulze-Lefert, P., and Ver Loren van Themaat, E. (2013). Mosaic genome structure of the barley powdery mildew pathogen and conservation of transcriptional programs in divergent hosts. Proc. Natl. Acad. Sci. U.S.A. 110, E2219-E2228. doi: 10.1073/pnas. 1306807110

Jafary, H., Albertazzi, G., Marcel, T. C., and Niks, R. E. (2008). High diversity of genes for nonhost resistance of barley to heterologous rust fungi. Genetics 178, 2327-2339. doi: 10.1534/genetics.107.077552

Jeuken, M. J. W., Pelgrom, K., Stam, P., and Lindhout, P. (2008). Efficient QTL detection for nonhost resistance in wild lettuce: backcross inbred lines versus F2 population. Theor. Appl. Genet. 116, 845-857. doi: 10.1007/s00122-008-0718-2

Jones, J. D. G., and Dangl, J. L. (2006). The plant immune system. Nature 444, 323-329. doi: 10.1038/nature05286

Jupe, F., Pritchard, L., Etherington, G. J., MacKenzie, K., Cock, P. J., Wright, F., et al. (2012). Identification and localisation of the NB-LRR gene family within the potato genome. BMC Genomics 13:75. doi: 10.1186/1471-2164-13-75

Jupe, F., Witek, K., Verweij, W., Sliwka, J., Pritchard, L., Etherington, G. J., et al. (2013). Resistance gene enrichment sequencing (RenSeq) enables reannotation of the NB-LRR gene family from sequenced plant genomes and rapid 
mapping of resistance loci in segregating populations. Plant J. 76, 530-544. doi: 10.1111/tpj.12307

Kang, S., Sweigard, J. A., and Valent, B. (1995). The PWL host specificity gene family in the blast fungus Magnaporthe grisea. Mol. Plant Microbe Interact. 8, 939-948. doi: 10.1094/MPMI-8-0939

Karasov, T. L., Horton, M. W., and Bergelson, J. (2014). Genomic variability as a driver of plant-pathogen coevolution? Curr. Opin. Plant Biol. 18, 24-30. doi: 10.1016/j.pbi.2013.12.003

Kaschani, F., Shabab, M., Bozkurt, T., Shindo, T., Schornack, S., Gu, C., et al. (2010). An effector-targeted protease contributes to defense against Phytophthora infestans and is under diversifying selection in natural hosts. Plant Physiol. 154, 1794-1804. doi: 10.1104/pp.110.158030

King, B. C., Waxman, K. D., Nenni, N. V., Walker, L. P., Bergstrom, G. C., and Gibson, D. M. (2011). Arsenal of plant cell wall degrading enzymes reflects host preference among plant pathogenic fungi. Biotechnol. Biofuels 4, 4. doi: 10.1186/1754-68344-4

Kombrink, A., and Thomma, B. P. H. J. (2013). LysM effectors: secreted proteins supporting fungal life. PLoS Pathog. 9:e1003769. doi: 10.1371/journal.ppat. 1003769

Lapin, D., and Van den Ackerveken, G. (2013). Susceptibility to plant disease: more than a failure of host immunity. Trends Plant Sci. 18, 546-554. doi: 10.1016/j.tplants.2013.05.005

Lee, H.-A., Kim, S.-Y., Oh, S.-K., Yeom, S.-I., Kim, S.-B., Kim, M.-S., et al. (2014). Multiple recognition of RXLR effectors is associated with nonhost resistance of pepper against Phytophthora infestans. New Phytol. 203, 926-938 doi: $10.1111 /$ nph.12861

Levesque, C. A., Brouwer, H., Cano, L., Hamilton, J. P., Holt, C., Huitema, E., et al. (2010). Genome sequence of the necrotrophic plant pathogen Pythium ultimum reveals original pathogenicity mechanisms and effector repertoire. Genome Biol. 11, R73. doi: 10.1186/gb-2010-11-7-r73

Lozano-Torres, J. L., Wilbers, R. H. P., Gawronski, P., Boshoven, J. C., FinkersTomczak, A., Cordewener, J. H. G., et al. (2012). Dual disease resistance mediated by the immune receptor Cf- 2 in tomato requires a common virulence target of a fungus and a nematode. Proc. Natl. Acad. Sci. U.S.A. 109, 10119-10124. doi: 10.1073/pnas.1202867109

Ma, L.-J., van der Does, H. C., Borkovich, K. A., Coleman, J. J., Daboussi, M.-J., Di Pietro, A., et al. (2010). Comparative genomics reveals mobile pathogenicity chromosomes in Fusarium. Nature 464, 367-373. doi: 10.1038/nature 08850

Maekawa, T., Kracher, B., Vernaldi, S., Ver Loren van Themaat, E., and SchulzeLefert, P. (2012). Conservation of NLR-triggered immunity across plant lineages. Proc. Natl. Acad. Sci. U.S.A. 109, 20119-20123. doi: 10.1073/pnas.12180 59109

Meyers, B. C. (2003). Genome-wide analysis of NBS-LRR-encoding genes in Arabidopsis. Plant Cell 15, 809-834. doi: 10.1105/tpc.009308

Mondragon-Palomino, M., Meyers, B. C., Michelmore, R. W., and Gaut, B. S. (2002) Patterns of positive selection in the complete NBS-LRR gene family of Arabidopsis thaliana. Genome Res. 12, 1305-1315. doi: 10.1101/gr.159402

Monosi, B., Wisser, R. J., Pennill, L., and Hulbert, S. H. (2004). Full-genome analysis of resistance gene homologues in rice. Theor. Appl. Genet. 109, 1434-1447. doi: 10.1007/s00122-004-1758-x

Morris, P. F., and Ward, E. W. B. (1992). Chemoattraction of zoospores of the soybean pathogen, Phytophthora sojae, by isoflavones. Physiol. Mol. Plant Pathol 40, 17-22. doi: 10.1016/0885-5765(92)90067-6

Mueller, A. N., Ziemann, S., Treitschke, S., Aßmann, D., and Doehlemann, G. (2013) Compatibility in the Ustilago maydis-maize interaction requires inhibition of host cysteine proteases by the fungal effector Pit2. PLoS Pathog. 9:e1003177. doi: 10.1371/journal.ppat.1003177

Niks, R. E., and Marcel, T. C. (2009). Nonhost and basal resistance: how to explain specificity? New Phytol. 182, 817-828. doi: 10.1111/j.1469-8137.2009. 02849.x

Palloix, A., Ayme, V., and Moury, B. (2009). Durability of plant major resistance genes to pathogens depends on the genetic background, experimental evidence and consequences for breeding strategies. New Phytol. 183, 190-199. doi: 10.1111/j.1469-8137.2009.02827.x

Pavan, S., Jacobsen, E., Visser, R. G. F., and Bai, Y. (2010). Loss of susceptibility as a novel breeding strategy for durable and broad-spectrum resistance. Mol. Breed. 25, 1-12. doi: 10.1007/s11032-009-9323-6
Pedersen, C., Ver Loren van Themaat, E., McGuffin, L., Abbott, J., Burgis, T., Barton, G., et al. (2012). Structure and evolution of barley powdery mildew effector candidates. BMC Genomics 13:694. doi: 10.1186/1471-2164-13-694

Porter, B. W., Paidi, M., Ming, R., Alam, M., Nishijima, W. T., and Zhu, Y. J. (2009). Genome-wide analysis of Carica papaya reveals a small NBS resistance gene family. Mol. Genet. Genomics 281, 609-626. doi: 10.1007/s00438-009-0434-x Qutob, D., Chapman, B. P., and Gijzen, M. (2013). Transgenerational gene silencing causes gain of virulence in a plant pathogen. Nat. Commun. 4, 1349. doi: 10.1038/ncomms 2354

Raffaele, S., Farrer, R. A., Cano, L. M., Studholme, D. J., MacLean, D., Thines, M., et al. (2010a). Genome evolution following host jumps in the Irish potato famine pathogen lineage. Science 330, 1540-1543. doi: 10.1126/science.1193070

Raffaele, S., Win, J., Cano, L. M., and Kamoun, S. (2010b). Analyses of genome architecture and gene expression reveal novel candidate virulence factors in the secretome of Phytophthora infestans. BMC Genomics 11:637. doi: 10.1186/14712164-11-637

Raffaele, S., and Kamoun, S. (2012). Genome evolution in filamentous plant pathogens: why bigger can be better. Nat. Rev. Microbiol. 10, 417-430. doi: $10.1038 /$ nrmicro 2790

Rice Genome Project. (2005). The map-based sequence of the rice genome. Nature 436, 793-800. doi: 10.1038/nature03895

Rouxel, T., Grandaubert, J., Hane, J. K., Hoede, C., van de Wouw, A. P., Couloux, A., et al. (2011). Effector diversification within compartments of the Leptosphaeria maculans genome affected by repeat-induced point mutations. Nat. Commun. 2, 202. doi: 10.1038/ncomms1189

Ruan, Y., Kotraiah, V., and Staraney, D. C. (1995). Flavonoids stimulate spore germination in Fusarium solani pathogenic on legumes in a manner sensitive to inhibitors of cAMP-dependent protein kinase. Mol. Plant Microbe Interact. 8, 929-938. doi: 10.1094/MPMI-8-0929

Saunders, D. G. O., Win, J., Cano, L. M., Szabo, L. J., Kamoun, S., and Raffaele, S. (2012). Using hierarchical clustering of secreted protein families to classify and rank candidate effectors of rust fungi. PLoS ONE 7:e29847. doi: 10.1371/journal.pone.0029847

Schulze-Lefert, P., and Panstruga, R. (2011). A molecular evolutionary concept connecting nonhost resistance, pathogen host range, and pathogen speciation. Trends Plant Sci. 16, 117-125. doi: 10.1016/j.tplants.2011.01.001

Schweizer, P. (2007). Nonhost resistance of plants to powdery mildew-new opportunities to unravel the mystery. Physiol. Mol. Plant Pathol. 70, 3-7. doi: 10.1016/j.pmpp.2007.07.004

Segretin, M. E., Pais, M., Franceschetti, M., Chaparro-Garcia, A., Bos, J. I., Banfield, M. J., et al. (2014). Single amino acid mutations in the potato immune receptor R3a expand response to Phytophthora effectors. Mol. Plant Microbe Interact. 27, 624-637. doi: 10.1094/MPMI-02-14-0040-R

Shabab, M., Shindo, T., Gu, C., Kaschani, F., Pansuriya, T., Chintha, R., et al. (2008). Fungal effector protein AVR2 targets diversifying defense-related Cys proteases of tomato. Plant Cell 20, 1169-1183. doi: 10.1105/tpc.107.056325

Shan, W., Cao, M., Leung, D., and Tyler, B. M. (2004). The Avrlb locus of Phytophthora sojae encodes an elicitor and a regulator required for avirulence on soybean plants carrying resistance gene Rps1b. Mol. Plant Microbe Interact. 17, 394-403. doi: 10.1094/MPMI.2004.17.4.394

Shen, D., Liu, T., Ye, W., Liu, L., Liu, P., Wu, Y., et al. (2013). Gene duplication and fragment recombination drive functional diversification of a superfamily of cytoplasmic effectors in Phytophthora sojae. PLOS ONE 8:e70036. doi: 10.1371/journal.pone.0070036

Shindo, T., and van der Hoorn, R. A. L. (2007). Papain-like cysteine proteases: key players at molecular battlefields employed by both plants and their invaders. Mol. Plant Pathol. 9, 119-125. doi: 10.1111/j.1364-3703.2007.00439.x

Sørensen, C. K., Justesen, A. F., and Hovmøller, M. S. (2013). Spontaneous loss of Yr2 avirulence in two lineages of Puccinia striiformis did not affect pathogen fitness. Plant Pathol. 62, 19-27. doi: 10.1111/ppa.12147

Spanu, P. D., Abbott, J. C., Amselem, J., Burgis, T. A., Soanes, D. M., Stüber, K., et al. (2010). Genome expansion and gene loss in powdery mildew fungi reveal tradeoffs in extreme parasitism. Science 330, 1543-1546. doi: $10.1126 /$ science. 1194573

Stam, R., Jupe, J., Howden, A. J. M., Morris, J. A., Boevink, P. C., Hedley, P. E., et al. (2013). Identification and characterisation of CRN effectors in Phytophthora capsici shows modularity and functional diversity. PLoS ONE 8:e59517. doi: 10.1371/journal.pone.0059517 
Stassen, J. H. M., den Boer, E., Vergeer, P. W. J., Andel, A., Ellendorff, U., Pelgrom, K., et al. (2013). Specific in planta recognition of two GKLR proteins of the downy mildew Bremia lactucae revealed in a large effector screen in lettuce. Mol. Plant Microbe Interact. 26, 1259-1270. doi: 10.1094/MPMI-05-130142-R

Stassen, J. H., and Van den Ackerveken, G. (2011). How do oomycete effectors interfere with plant life? Curr. Opin. Plant Biol. 14, 407-414. doi: 10.1016/j.pbi.2011.05.002

Stirnweis, D., Milani, S. D., Jordan, T., Keller, B., and Brunner, S. (2014). Substitutions of two amino acids in the nucleotide-binding site domain of a resistance protein enhance the hypersensitive response and enlarge the PM3F resistance spectrum in wheat. Mol. Plant Microbe Interact. 27, 265-276. doi: 10.1094/MPMI-10-13-0297-FI

Stukenbrock, E. H., and Croll, D. (2014). The evolving fungal genome. Fungal Biol. Rev. 28, 1-12. doi: 10.1016/j.fbr.2014.02.001

Stukenbrock, E. H., and McDonald, B. A. (2009). Population genetics of fungal and oomycete effectors involved in gene-for-gene interactions. Mol. Plant Microbe Interact. 22, 371-380. doi: 10.1094/MPMI-22-4-0371

Stuttmann, J., Hubberten, H.-M., Rietz, S., Kaur, J., Muskett, P., Guerois, R., et al (2011). Perturbation of Arabidopsis amino acid metabolism causes incompatibility with the adapted biotrophic pathogen Hyaloperonospora arabidopsidis. Plant Cell 23, 2788-2803. doi: 10.1105/tpc.111.087684

Sweigard, J. A., Caroll, A. M., Kang, S., Farrall, L., Chumley, F. G., and Valent B. (1995). Identification, cloning, and characterization of PWL2, a gene for host species specificity in the rice blast fungus. Plant Cell 7, 1221-1233. doi: 10.1105/tpc.7.8.1221

Tian, M., Win, J., Song, J., van der Hoorn, R., van der Knaap, E., and Kamoun, S. (2006). A Phytophthora infestans cystatin-like protein targets a novel tomato papain-like apoplastic protease. Plant Physiol. 143, 364-377. doi: 10.1104/pp.106.090050

Tosa, Y., Tamba, H., Tanaka, K., and Mayama, S. (2006). Genetic analysis of host species specificity of Magnaporthe oryzae isolates from rice and wheat. Phytopathology 96, 480-484. doi: 10.1094/PHYTO-960480

Uma, B., Swaroopa Rani, T., and Podile, A. R. (2011). Warriors at the gate that never sleep: non-host resistance in plants. J. Plant Physiol. 168, 2141-2152. doi: 10.1016/j.jplph.2011.09.005

van Schie, C. C. N., and Takken, F. L. W. (2014). Susceptibility genes 101: how to be a good host. Annu. Rev. Phytopathol. 52, 551-581. doi: 10.1146/annurev-phyto102313-045854

Vega-Arreguín, J. C., Jalloh, A., Bos, J. I., and Moffett, P. (2014). Recognition of an Avr3a homologue plays a major role in mediating nonhost resistance to Phytophthora capsici in Nicotiana species. Mol. Plant Microbe Interact. 27, 770-780. doi: 10.1094/MPMI-01-140014-R
Vogel, J. P., Raab, T. K., Schiff, C., and Somerville, S. C. (2002). PMR6, a pectate lyase-like gene required for powdery mildew susceptibility in Arabidopsis. Plant Cell 14, 2095-2106. doi: 10.1105/tpc.003509

Wawra, S., Belmonte, R., Löbach, L., Saraiva, M., Willems, A., and van West, P. (2012). Secretion, delivery and function of oomycete effector proteins. Curr. Opin. Microbiol. 15, 685-691. doi: 10.1016/j.mib.2012.10.008

Win, J., Morgan, W., Bos, J., Krasileva, K. V., Cano, L. M., Chaparro-Garcia, A., et al. (2007). Adaptive evolution has targeted the C-terminal domain of the RXLR effectors of plant pathogenic oomycetes. Plant Cell 19, 2349-2369. doi: $10.1105 /$ tpc.107.051037

Wulff, B. B. H., Horvath, D. M., and Ward, E. R. (2011). Improving immunity in crop: new tactics in an old game. Curr. Opin. Plant Biol. 14, 468-476. doi: 10.1016/j.pbi.2011.04.002

Zellerhoff, N., Himmelbach, A., Dong, W., Bieri, S., Schaffrath, U., and Schweizer, P. (2010). Nonhost resistance of barley to different fungal pathogens is associated with largely distinct, quantitative transcriptional responses. Plant Physiol. 152, 2053-2066. doi: 10.1104/pp.109.151829

Zhang, N. W., Pelgrom, K., Niks, R. E., Visser, R. G. F., and Jeuken, M. J. W. (2009). Three combined quantitative trait loci from nonhost Lactuca saligna are sufficient to provide complete resistance of lettuce against Bremia lactucae. Mol. Plant Microbe Interact. 22, 1160-1168. doi: 10.1094/MPMI-22-9-1160

Zheng, X., McLellan, H., Fraiture, M., Liu, X., Boevink, P. C., Gilroy, E. M., et al. (2014). Functionally redundant RXLR effectors from Phytophthora infestans act at different steps to suppress early flg22-triggered immunity. PLoS Pathog. 10:e1004057. doi: 10.1371/journal.ppat.1004057

Zipfel, C. (2009). Early molecular events in PAMP-triggered immunity. Curr. Opin. Plant Biol. 12, 414-420. doi: 10.1016/j.pbi.2009.06.003

Conflict of Interest Statement: The authors declare that the research was conducted in the absence of any commercial or financial relationships that could be construed as a potential conflict of interest.

Received: 30 July 2014; accepted: 08 October 2014; published online: 05 November 2014.

Citation: Stam R, Mantelin S, McLellan H and Thilliez G (2014) The role of effectors in nonhost resistance to filamentous plant pathogens. Front. Plant Sci. 5:582. doi: 10.3389/fpls.2014.00582

This article was submitted to Plant-Microbe Interaction, a section of the journal Frontiers in Plant Science.

Copyright (C) 2014 Stam, Mantelin, McLellan and Thilliez. This is an open-access article distributed under the terms of the Creative Commons Attribution License (CC BY). The use, distribution or reproduction in other forums is permitted, provided the original author(s) or licensor are credited and that the original publication in this journal is cited, in accordance with accepted academic practice. No use, distribution or reproduction is permitted which does not comply with these terms. 